\title{
Penerima Manfaat Bantuan Non Tunai Kartu Keluarga Sejahtera Menggunakan Metode NAÏVE BAYES dan KNN
}

\author{
Haidah Putri ${ }^{1}$, Ade Irma Purnamasari ${ }^{1}$, Arif Rinaldi Dikananda ${ }^{2}$, Odi Nurdiawan ${ }^{3, *}$, Saeful Anwar ${ }^{1}$ \\ ${ }^{1}$ Program Studi Teknik Informatika, STMIK IKMI Cirebon, Cirebon, Indonesia \\ ${ }^{2}$ Program Studi Rekayasa Perangkat Lunak, STMIK IKMI Cirebon, Cirebon, Indonesia \\ ${ }^{3}$ Program Studi Manajemen Informatika, STMIK IKMI Cirebon, Cirebon, Indonesia \\ Email: ${ }^{1}$ Haidahputrid@ gmail.com, ${ }^{2}$ irma2974@yahoo.com, ${ }^{3}$ rinaldi23crb@ gmail.com, ${ }^{4, *}$ odinurdiawan2020@gmail.com, \\ ${ }^{5}$ saefulanwar419@gmail.com \\ Email Penulis Korespondensi: odinurdiawan2020@gmail.com \\ Submitted: 20/12/2021; Accepted: 28/12/2021; Published: 31/12/2021
}

\begin{abstract}
Abstrak-Kartu Keluarga Sejahtera merupakan salah satu program pemerintah dalam percepatan penanggulangan kemiskinan yang berfungsi sebagai penanda masyarakat kurang mampu. Implementasi kebijakan KKS masih belum optimal karena faktor kurangnya sosialisasi dan informasi dari aparat desa dan kecamatan kepada masyarakat mengenai program yang dikeluarkan pemerintah. Penelitian ini bertujuan untuk mengklasifikasikan penerima manfaat Kartu Keluarga Sejahtera, karena masih banyak keluarga yang tidak mempu lainnya yang belum berkesempatan menerima program bantuan ini. Metode yang digunakan adalah metode Naive Bayes dan metode K-NN. Hasil dari penelitian ini adalah klasifikasi penerima manfaat dari 6.491 penerima KKS dengan metode Algoritma K-NN menghasilkan nilai accuracy 66,46\% dengan sebaran di 5 kelurahan antara lain pred Argasunya class precision $64,90 \%$ pred Harjamukti class precision $65,18 \%$ pred Kalijaga class precision 66,64\% pred Kecapi class precision 68,44\% pred Larangan class precision 68,34\% sedangkan algoritma Naïve Bayes terklasifikasi dengan true di masing-masing kelurahan dengan sebaran true Argasunya 1.196 KKS class precision 100\%, true Harjamukti 1.339 KKS class precision 100\%, true Kalijaga 2.067 KKS class precision 100\%, true Kecapi $1.137 \mathrm{KKS}$ class precision 100\%, true Larangan $744 \mathrm{KKS}(1 \mathrm{KKS}$ true Argasunya, 1 KKS true Harjamukti, $3 \mathrm{KKS}$ true Kalijaga, $3 \mathrm{KKS}$ true Kecapi) class precision 98.64\%. nilai accurasy model algoritma Nä̈ve Bayes sebesar $99,88 \%$.
\end{abstract}

Kata Kunci: Data Mining; Nä̈ve Bayes; $K-N N$; Klasifikasi; KKS

\begin{abstract}
The Prosperous Family Card is one of the government's programs in accelerating poverty which functions as a marker for the underprivileged. The implementation of the PSC policy is still not optimal due to factors, namely the lack of socialization and information from village and sub-district officials to the community regarding programs issued by the government. This research to classify the beneficiaries of the Prosperous Family Card, because there are still many other disadvantaged families who have not had the opportunity to receive this assistance program. The method used in this research is the Naive Bayes method and the K-NN method. The results of this study are the classification of beneficiaries from 6,491 KKS recipients with the K-NN Algorithm method yielding an accuracy value of $66.46 \%$ with a distribution in 5 villages, including pred Argasunya class precision $64.90 \%$ pred Harjamukti class precision $65.18 \%$ pred Kalijaga class precision $66.64 \%$ pred Kecapi class precision $68.44 \%$ pred Prohibition class precision $68.34 \%$ while the Naïve Bayes algorithm is classified with true in each kelurahan with true Argasunya distribution of 1,196 KKS class precision 100\%, true Harjamukti 1,339 KKS class precision 100\%, true Kalijaga 2,067 KKS class precision $100 \%$, true Kecapi 1,137 KKS class precision 100\%, true Prohibition 744 KKS(1 KKS true Argasunya, 1 KKS true Harjamukti, 3 KKS true Kalijaga, 3 KKS true Kecapi) class precision 98.64\%. the accurasy value of the Naïve Bayes algorithm model is $99.88 \%$.
\end{abstract}

Keywords: Data Mining; Nä̈ve Bayes; K-NN; Classification; KKS

\section{PENDAHULUAN}

Kemiskinan adalah rendahnya kemampuan seseorang, sekelompok orang atau wilayah. Secara umum faktor-faktor penyebab kemiskinan secara kategoris dengan menitiberatkan kajian pada sumbernya terdiri dari dua bagian besar, yaitu faktor internal dan faktor eksternal.[1] Selama ini, pemerintah Indonesia telah banyak memiliki programprogram untuk pengentasan kemiskinan yang ada.[2] Kartu Keluarga Sejahtera (KKS) merupakan salah satu program pemerintah dalam percepatan penanggulangan kemiskinan yang tercantum pada Peraturan Presiden (Perpres) nomor 166 Tahun 2014 tentang penanggulangan kemiskinan. Selain sebagai penanda masyarakat kurang mampu, KKS juga berfungsi sebagai kartu identitas untuk mendapatkan Program Simpanan Keluarga Sejahtera (PSKS). Berdasarkan Basis Data Terpadu (BDT) yang diolah oleh Tim Nasional Percepatan Penanggulangan Kemiskinan (TNP2KP), penerima bantuan KKS sebanyak 25\% dari total jumlah penduduk yang ada dengan status sosial ekonomi terendah dengan jumlah kisaran bantuan yang diberikan sebesar Rp.200.000/keluarga/perbulan.[3] karena masih banyak keluarga tidak mampu lainnya yang belum berkesempatan menerima program bantuan ini.[4]Mengingat banyaknya kriteria dan jumlah masyarakat yang akan menerima KKS, maka akan membuat tim seleksi mengalami kesulitan dalam melakukan penyeleksian.[5]

Kecamatan Harjamukti merupakan salah satu daerah yang masuk dalam program Kartu Keluarga Sejahtera. Namun dalam pelaksanaannya ditemukan permasalahan dalam penentuan rumah tangga penerima KKS diantaranya penilaian yang kurang objektif dan proses penyeleksiannya yang berjalan cukup lambat. Berdasarkan permasalahan ini, diperlukan pendataan ulang dan validasi data oleh aparat kelurahan. Dalam menentukan rumah tangga yang berhak menerima bantuan KKS, diperlukan suatu metode yang terstruktur dan terkomputerisasi agar penyeleksian bersifat objektif, Metode yang akan digunakan adalah metode Klasifikasi K- Neares Neighbor yaitu Proses klasifikasi terhadap 
objek berdasarkan data pembelajaran yang objek terdekat.[6] dan metode Klasifikasi Naïve Bayes yang merupakan salah satu teknik pengklasifikasian dalam data mining. Dimana akan dilakukan analisis untuk memperoleh informasi terhadap data lama tingkat kemiskinan. Diharapkan dari penelitian yang dilakukan terhadap sampel data penduduk miskin tersebut dapat diperoleh suatu informasi yang bisa membantu pihak kecamatan untuk merancang strategi dalam meningkatkan kesejahteraan masyarakat.[7]

Kartu Keluarga Sejahtera (KKS) berfungsi sebagai penanda masyarakat kurang mampu dan juga sebagai kartu identitas untuk mendapatkan Program Simpan Keluarga Sejahtera. Namun terkadang bantuan KKS kurang tepat sasaran. Hal ini disebabkan karena penilaian calon penerima bantuan Kartu Keluarga Sejahtera (KKS) bersifat subjektif serta proses penyeleksian berjalan cukup lambat. Penelitian ini dilakukan dengan tujuan untuk merancang sistem informasi pendukung keputusan berbasis web dengan menggunakan metode TOPSIS (Technique For Order Of Preference by Similarity To Ideal) pada proses penyeleksian calon penerima bantuan KKS. Hasil dari penelitian ini adalah sebuah sistem informasi yang dapat menghasilkan urutan calon penerima bantuan KKS sebagai bahan pertimbangan dalam menentukan penerima bantuan KKS. Dengan adanya sistem informasi ini, pengolahan data dapat dilakukan secara cepat, tepat dan proses penilaian calon penerima bantuan KKS menjadi lebih objektif.[3]

Pemantauan lapangan di Kelurahan Yukum Jaya, Kecamatan Terbanggi Besar, Kabupaten Lampung Tengah terdapat beberapa masalah yang terjadi mengenai salah sasaran yang disebabkan kesalahan data jumlah keluarga miskin, jumlah beras yang dibagikan tidak sesuai metode penelitian yang digunakan adalah survei dengan lokasi penelitian di Kelurahan Yukum Jaya Kecamatan Terbanggi Besar Kabupaten Lampung Tengah. Penentuan lokasi dilakukan secara sengaja (purposive) dengan pertimbangan bahwa , lokasi ini dipilih karena jumlah penerima manfaat bantuan di Kelurahan Yukum Jaya yang cukup tinggi pada Kabupaten Lampung Tengah. Waktu pengumpulan data dan pelaksanaan penelitian dilakukan pada bulan Juli 2019-Agustus 2019. Hasil dari penelitian Sistem distribusi dari program bantuan Rastra dan BPNT masuk dalam kategori distribusi semi langsung. Dari hasil efisiensi distribusi pada program Rastra sebesar 0,06 dan pada program BPNT sebesar 0,04 yang berarti bahwa pendistribusian kedua program bantuan pemerintah ini dinyatakan efisien. Nilai dengan menggunakan metode CSI diketahui bahwa program Rastra berada pada kriteria cukup tepat yaitu sebesar 54,36 persen, sedangkan pada program BPNT berada pada kriteria tepat yaitu sebesar 68,94 persen, hasil perhitungan tingkat kesesuaian antara kinerja dan harapan dengan metode IPA pada program Rastra atribut kurang sesuai (38 persen) adalah aribut tepat jumlah, sedangkan program BPNT atribut kurang sesuai (40 persen) adalah atribut kebersihan beras.[8]

Berdasarkan uraian tersebut dalam penelitian ini, metode algoritma Naïve Bayes dan K-Nearst Neighbor akan digunakan untuk mengklasifikasikan data penerima manfaat bantuan non tunai Kartu Keluarga Sejahtera di Kecamatan Harjamukti serta pengaruhnya penggunaan machine learning dalam penentuan warga penerima manfaat bantuan non tunai kartu keluarga sejahtera di kecamatan Harjamukti dan hasil penelitian ini dapat dijadikan sebagai alternatif dalam pengambilan keputusan di tingkat kecamatan.

\section{METODOLOGI PENELITIAN}

\subsection{Landasan Teori}

\section{Data Mining}

Data mining dapat di artikan sebagai data dalam jumlah besar yang di simpan dalam suatu database. Data mining memanfaatkan pengalaman atau bahkan kesalahan di masa lalu untuk meningkatkan kualitas dari model maupun hasil analisisnya, salah satunya dengan kemampuan yang dimiliki teknik data mining yaitu klasifikasi.[9]

2. Klasifikasi

Metode klasifikasi adalah salah satu metode yang paling sering digunakan, di dalam metode klasifikasi salah satu teknik yang digunakan adalah Neural Network yang sering digunakan untuk menyelesaikan masalahmasalah yang rumit dan berkaitan dengan identifikasi input, prediksi, pengenalan pola dan sebagainya.[10]

\section{Naive bayes}

Naïve Bayes merupakan sebuah pengklasifikasian probabilistik sederhana yang menghitung sekumpulan probabilitas dengan menjumlahkan frekuensi dan kombinasi nilai dari dataset yang diberikan.[3] Algoritma mengunakan Teorema Bayes dan mengasumsikan semua atribut independen atau tidak saling ketergantungan yang diberikan oleh nilai pada variabel kelas. Definisi lain mengatakan Naïve Bayes merupakan pengklasifikasian dengan metode probabilitas dan statistik yang dikemukan oleh ilmuwan Inggris Thomas Bayes, yaitu memprediksi peluang di masa depan berdasarkan pengalaman di masa sebelumnya.[11]

$P(X \mid Y)=\frac{P(Y \mid X) \cdot(X)}{P(Y)}$

dimana :

$\mathrm{P}(\mathrm{X} \mid \mathrm{Y})=$ Posterior|probability yaitu nilai probabilitas $\mathrm{X}$ berdasarkan kondisi $\mathrm{Y}$

$\mathrm{P}(\mathrm{Y} \mid \mathrm{X})=$ probabilitas $\mathrm{Y}$ yang ditentukan $\mathrm{X}$ adalah benar

$\mathrm{P}(\mathrm{X})=$ Peluang evidence penyakit $\mathrm{X}$

$\mathrm{P}(\mathrm{Y})=$ Probabilitas dari nilai $\mathrm{Y}$ 


\section{K Neirest Neightor}

Metode K-Nearest Neighbor adalah metode melakukan klasifikasi terhadap objek berdasarkan data pembelajaran yang jaraknya paling dekat dengan objek tersebut. Metode ini bertujuan untuk mengklasifikasi- kan objek baru berdasarkan atribut dan training sample. Nilai prediksi dari query akan ditentukan berdasarkan klasifikasi tetanggaan Dari pengertian sebelumnya Metode K-NN dapat diartikan suatu metode yang dapat mengklasifikasi berdasarkan data paling dekat berdasarkan tetangga atau data sebelumnya yang dimiliki sebagai sample untuk menemukan hasil akhir.[12]

\section{Rapid Miner}

RapidMiner merupakan software/perangkat lunak untuk pengolahan data. Dengan menggunakan prinsip dan algoritma data mining, RapidMiner mengekstrak pola-pola dari data set yang besar dengan mengkombinasikan metode statistika, kecerdasan buatan dan database.[13]

\subsection{Tahapan Penelitian}

Metode penelitian yang digunakan dalam penelitian ini menggunakan Knowledge Discovery in Database (KDD) yaitu proses yang bertujuan untuk menggali dan menganalisis data yang sangat besar menjadi informasi yang berguna untuk pengetahuan. Algoritma yang digunakan dalam melakukan klasifikasi penerima manfaat bantuan non tunai kartu keluarga sejahtera menggunakan metode algoritma Naïve Bayes dan KNN



Gambar 1. Alur Penelitian KDD

Tahapan penelitian yang akan dilakukan pada penelitian ini berdasarkan proses KDD terdiri dari tahapan-tahapan sebagai berikut:

1. Data selection

Pemilihan data yang relevan dan dapat dilakukan analisis dari data operasional. Data disatukan ke dalam sebuah tabel.

2. Preprocessing Data

Preprocessing data merupakan Langkah pertama yang harus dilakukan untuk pembersihan data atau data cleaning.

3. Transformasi Data

Proses tranformasi data kedalam bentuk format tertentu sehingga data tersebut sesuai untuk proses data mining.

4. $\quad$ Data mining

Proses mencari pola atau informasi menarik dengan menggunakan teknik, metode atau algoritma tertentu. Dalam penelitian ini dilakukan proses menggunakan algoritma Naïve Bayes dan K-Nearst Neighbor

5. Tahapan Evaluasi dan Interpretasi

Menyimpulkan pola-pola dari hasil data mining. Menampilkan pola informasi yang dihasilkan dari proses klasifikasi, proses ini memaparkan hasil sehingga menjadi informasi yang mudah dipahami.

\subsection{Teknik Penyajian Data}

Distribusi Variabel adalah segala sesuatu yang berbentuk apa saja yang ditetapkan oleh seorang peneliti dengan tujuan untuk dipelajari sehingga didapatkan informasi mengenai hal tersebut dan ditariklah sebuah kesimpulan

Tabel 2. Variabel X dan Y

\begin{tabular}{|c|c|c|c|}
\hline Variabel & Definisi & Indikator & Fokus Pertanyaan \\
\hline $\begin{array}{l}\text { (X) Penerima manfaat } \\
\text { bantuan non tunai kartu } \\
\text { keluarga sejahtera }\end{array}$ & $\begin{array}{l}\text { Penerima manfaat } \\
\text { merupakan data keluarga } \\
\text { sejahtera yang } \\
\text { mendapatkan bantuan }\end{array}$ & $\begin{array}{l}\text { 1. Melihat hasil } \\
\text { penerima manfaat } \\
\text { bantuan non tunai }\end{array}$ & $\begin{array}{l}\text { Mengevaluasi dalam } \\
\text { menentukan penerima manfaat } \\
\text { bantuan non tunai. }\end{array}$ \\
\hline
\end{tabular}




\begin{tabular}{|c|c|c|c|}
\hline Variabel & Definisi & Indikator & Fokus Pertanyaan \\
\hline $\begin{array}{l}\text { Berdasarkan proses } \\
\text { Pembelajaran } \\
\text { Klasifikasi data } \\
\text { penerima manfaat }(\mathrm{Y})\end{array}$ & $\begin{array}{l}\text { Melakukan klasifikasi } \\
\text { terhadap data penerima } \\
\text { manfaat bantuan non } \\
\text { tunai. }\end{array}$ & $\begin{array}{l}\text { 2. Menjelaskan } \\
\text { dengan lisan } \\
\text { sendiri. } \\
\text { 1. Laporan } \\
\text { Klasifikasi data } \\
\text { 2. Akurasi jumlah } \\
\text { penerima manfaat } \\
\text { bantuan non tunai }\end{array}$ & $\begin{array}{l}\text { 1. Output yang dihasilkan sesuai } \\
\text { dengan data yang diolah.? } \\
\text { 2. Penerapan Metode Algoritma } \\
\text { Naïve Bayes dalam } \\
\text { Menentukan Klasifikasi } \\
\text { bantuan non tunai? }\end{array}$ \\
\hline
\end{tabular}

\section{HASIL DAN PEMBAHASAN}

\subsection{Data Selection}

Pada tahapan ini data yang digunakan akan diseleksi dengan cara melihat, kesesuaian data dengan topik atau judul penelitian yang akan di teliti, dalam hal ini data yang diperoleh dari kecamatan Harjamukti sudah sesuai dengan format data mining yang terdiri dari atribut NIK_Dinsos, Nama_Dinsos, Tgl_LHR_Dinsos, Pekerjaan, Penghasilan KK, Jumlah Tanggungan, Pendidikan, Kondisi Bangunan, Jenis Kelamin, RT, RW, Kelurahan.

\subsection{Preprocessing Data}

Tahapan preprocessing data dalam penelitian ini menggunakan operator normalize pada tool rapidminer. operator Normalize akan melakukan Transformasi z (juga dikenal sebagai Standarisasi) yang menghasilkan nilai rata-rata 0 dan deviasi standar 1 untuk setiap atribut. Dengan kata lain, semua atribut berada pada skala yang sama setelah normalisasi dan dapat dibandingkan satu sama lain. Adapun operator normalize seperti tampak pada gambar 3.1 Operator Normalize

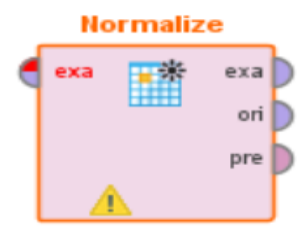

Gambar 2. Operator Normalize

\subsection{Transformasi data}

Ada pun pada tahap ini data akan diubah menjadi bentuk yang sesuai untuk proses data mining. Karena dalam penelitian ini akan dilakukan uji coba secara teoritis dan mengunakan software data mining yaitu RapidMiner, maka data yang telah melalui proses sebelumnya akan di transformasi agar dapat sesuai dengan algoritma yang dipakai yaitu algoritma Naïve Bayes dan K-Nearst Neighbor. Pada tahapan ini atribut yang di pakai akan diberi label mengikuti kondisi data - data pada atribut tersebut. Dibawah ini adalah data set terdiri dari 6 record yang sudah melalui proses.

Tabel 3. Tabel Dataset Penerima Manfaat Bantuan Non Tunai Kartu Keluarga Sejahtera di Kecamatan Harjamukti

\begin{tabular}{|c|c|c|c|c|c|c|}
\hline NO & NO_KK & NIK_DINSOS & NAMA_DINSOS & $\begin{array}{c}\text { TGL_LHR_ } \\
\text { DINSOS }\end{array}$ & PEKERJAAN & $\begin{array}{c}\text { PENGHASILAN } \\
\text { KK } \\
\end{array}$ \\
\hline 1 & 3274031804070160 & 3274032004550005 & SALEH & $20 / 04 / 1955$ & TIDAK BEKERJA & RENDAH \\
\hline 2 & 3274012505070105 & 3274010108720003 & AGUS MULYADI & 01/08/1972 & BURUH & CUKUP \\
\hline 3 & 3274031704070012 & 3274030505720017 & MAHMUD & 05/05/1972 & KULI BANGUNAN & RENDAH \\
\hline 4 & 3274031704070016 & 3274031012720009 & SUTAMA PRAWIRA ATMAJA & 10/12/1972 & BURUH & CUKUP \\
\hline 5 & 3274032704070018 & 3274031506510050 & SUKENDRA & $15 / 06 / 1951$ & TIDAK BEKERJA & RENDAH \\
\hline 6491 & 3274030609070028 & 3274030405570006 & HERMAN HARDIYANTO & $04 / 05 / 1957$ & TIDAK BEKERJA & RENDAH \\
\hline 6492 & 3274031212140005 & 3274051406500001 & DEDDY JUNAEDY & $14 / 06 / 1950$ & TIDAK BEKERJA & RENDAH \\
\hline
\end{tabular}

Tabel Lanjutan 3. Tabel Dataset Penerima Manfaat Bantuan Non Tunai Kartu Keluarga Sejahtera di Kecamatan Harjamukti

\begin{tabular}{|c|c|c|c|c|c|c|c|}
\hline $\begin{array}{c}\text { JUMLAH } \\
\text { TANGGUNGAN } \\
\end{array}$ & PENDIDIKAN & $\begin{array}{c}\text { KONDISI BANGUNAN } \\
\text { RUMAH }\end{array}$ & $\begin{array}{c}\text { JENIS } \\
\text { KELAMIN }\end{array}$ & ALAMAT & $\begin{array}{c}\mathrm{NO}_{\mathrm{P}} \mathrm{R} \\
\mathrm{T}\end{array}$ & $\begin{array}{c}\mathrm{NO}_{\mathrm{W}} \mathrm{R} \\
\mathrm{W}\end{array}$ & $\begin{array}{c}\text { KELURAH } \\
\text { AN }\end{array}$ \\
\hline 1 & $\begin{array}{c}\text { TIDAK } \\
\text { SEKOLAH }\end{array}$ & SEMI PERMANEN & LAKI-LAKI & ARGAPURA & 1 & 1 & $\begin{array}{l}\text { ARGASUN } \\
\text { YA }\end{array}$ \\
\hline 2 & SMP & SEMI PERMANEN & LAKI-LAKI & ARGAPURA & 1 & 1 & $\begin{array}{l}\text { ARGASUN } \\
\text { YA }\end{array}$ \\
\hline 1 & SD & PAPAN & LAKI-LAKI & ARGAPURA & 1 & 1 & $\begin{array}{l}\text { ARGASUN } \\
\text { YA }\end{array}$ \\
\hline$>2$ & SMP & SEMI PERMANEN & LAKI-LAKI & ARGAPURA & 1 & 1 & $\begin{array}{l}\text { ARGASUN } \\
\text { YA }\end{array}$ \\
\hline 1 & $\begin{array}{l}\text { TIDAK } \\
\text { SEKOLAH }\end{array}$ & PAPAN & LAKI-LAKI & ARGAPURA & 1 & 1 & $\begin{array}{l}\text { ARGASUN } \\
\text { YA }\end{array}$ \\
\hline
\end{tabular}


Building of Informatics, Technology and Science (BITS)

Volume 3, No 3, Desember 2021 Page: 331-337

ISSN 2684-8910 (media cetak)

ISSN 2685-3310 (media online)

DOI 10.47065/bits.v3i3.1093

\begin{tabular}{|c|c|c|c|c|c|c|c|}
\hline $\begin{array}{c}\text { JUMLAH } \\
\text { TANGGUNGAN }\end{array}$ & PENDIDIKAN & $\begin{array}{l}\text { KONDISI BANGUNAN } \\
\text { RUMAH }\end{array}$ & $\begin{array}{c}\text { JENIS } \\
\text { KELAMIN }\end{array}$ & ALAMAT & $\underset{\mathrm{T}}{\mathrm{NO} \mathrm{R}^{-}}$ & $\mathrm{W}_{\mathrm{W}}^{\mathrm{NO}}$ & $\begin{array}{c}\text { KELURAH } \\
\text { AN }\end{array}$ \\
\hline 0 & $\begin{array}{c}\text { TIDAK } \\
\text { SEKOLAH }\end{array}$ & PAPAN & LAKI-LAKI & $\begin{array}{l}\text { JL. GN MURIA III } \\
\text { NO.47 }\end{array}$ & 8 & 19 & $\begin{array}{c}\text { LARANGA } \\
\mathrm{N}\end{array}$ \\
\hline 0 & SD & SEMI PERMANEN & LAKI-LAKI & $\begin{array}{c}\text { JL GN.MURIA II } \\
\text { NO. } 27\end{array}$ & 8 & 19 & $\begin{array}{c}\text { LARANGA } \\
\mathrm{N}\end{array}$ \\
\hline
\end{tabular}

\subsection{Data Mining}

Tahapan data mining pada penelitian ini menggunakan algoritma Naïve Bayes dan K-Nearst Neighbor. Data tersebut akan distandarisasi mengikuti proses tahapan data mining agar data tersebut layak dan dapat diolah menggunakan rapidminer dengan metode algoritma Naïve Bayes dan K-Nearst Neighbor. Pengujian dengan aplikasi yang telah ditentukan. Hasil dari analisis diuji lagi dengan menggunakan software RapidMiner Studio.

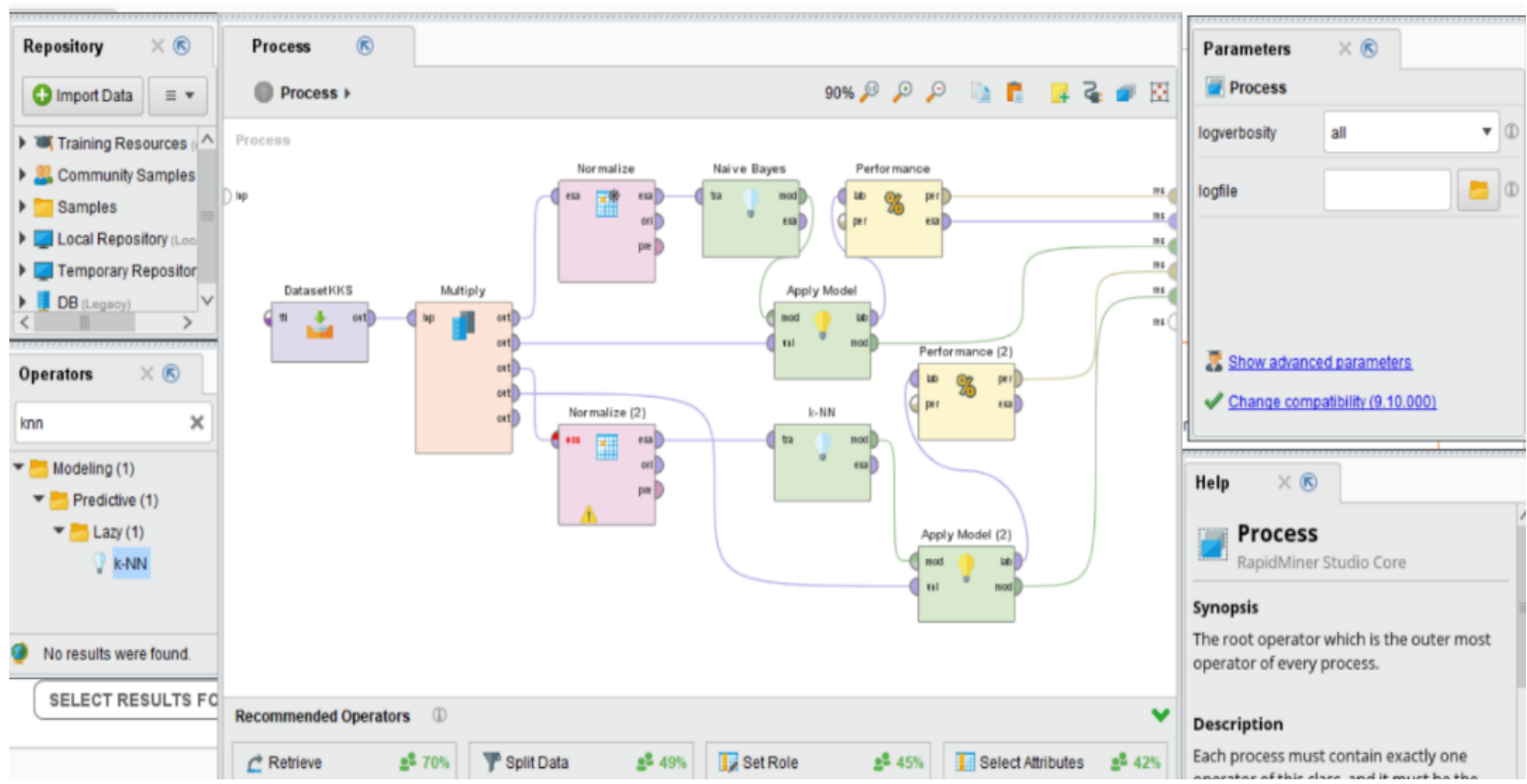

Gambar 3. Model Proses Algoritma Naïve Bayes dan Algoritma K_Nearst Neighbor

\subsection{Tahapan Evaluasi dan Interpretasi}

Berdasarkan tujuan dari penelitian untuk dapat menggunakan machine learning dalam melakukan klasifikasi data penerima manfaat bantuan non tunai kartu keluarga sejahtera di kecamatan Harjamukti bahwa dari 6.491 record berdasarkan hasil dari performanceVector Algoritma Nä̈ve Bayes seperti pada gambar 4.9 bahwa data penerima manfaat bantuan non tunai Kartu Keluarga Sejahtera terklasifikasikan berada di Kecamatan Harjamukti, dengan sebaran di 5 kelurahan antara lain : true Argasunya 1.196 KKS class precision 100\%, true Harjamukti $1.339 \mathrm{KKS}$ class precision 100\%, true Kalijaga 2.067 KKS class precision 100\%, true Kecapi 1.137 KKS class precision 100\%, true Larangan $744 \mathrm{KKS}(1 \mathrm{KKS}$ true Argasunya, $1 \mathrm{KKS}$ true Harjamukti, 3 KKS true Kalijaga, 3 KKS true Kecapi) class precision 98.64\%. nilai accurasi model algoritma Nä̈ve Bayes sebesar 99,88\%.

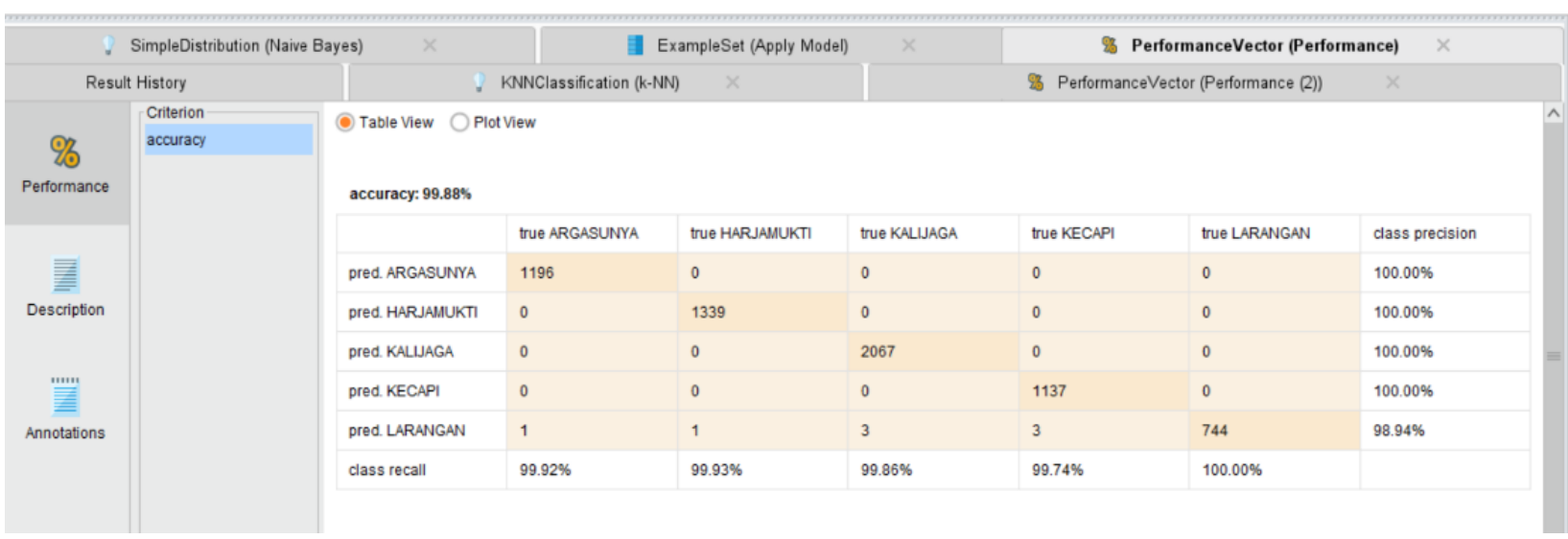

Gambar 4. PerformanceVector Algoritma Naïve Bayes

Berdasarkan tujuan dari penelitian untuk dapat menggunakan machine learning dalam melakukan klasifikasi data penerima manfaat bantuan non tunai kartu keluarga sejahtera di kecamatan Harjamukti bahwa dari 6.491 record 
berdasarkan hasil dari performanceVector Algoritma K-Nearst Neighbor seperti pada gambar 4.11 bahwa data penerima manfaat bantuan non tunai Kartu Keluarga Sejahtera terklasifikasikan berada di Kecamatan Harjamukti, dengan sebaran di 5 kelurahan antara lain : pred Argasunya class precision 64.90\% dengan sebaran (true Argasunya $760 \mathrm{KKS}$, true Harjamukti $117 \mathrm{KKS}$, true Kalijaga $145 \mathrm{KKS}$, true Kecapi $90 \mathrm{KKS}$, true Larangan 59 KKS, pred. Harjamukti class precision $65.18 \%$ dengan sebaran ( true Argasunya $128 \mathrm{KKS}$, true Harjamukti $893 \mathrm{KKS}$, true Kalijaga 188, true Kecapi $89 \mathrm{KKS}$, true Larangan $72 \mathrm{KKS}$, pred. Kalijaga class precision $66.64 \%$ dengan sebaran (true Argasunya 202 KKS, true Harjamukti 218 KKS, true Kalijaga 1.546 KKS, true Kecapi 212 KKS, true Larangan $142 \mathrm{KKS}$, pred. Kecapi class precision $68.44 \%$ dengan sebaran (true Argsunya $71 \mathrm{KKS}$, true Harjamukti 64 KKS, true Kalijaga $128 \mathrm{KKS}$, true Kecapi $707 \mathrm{KKS}$, true Larangan $63 \mathrm{KKS}$, pred. Larangan class precision 68.34\% dengan sebaran (true Argsunya $36 \mathrm{KKS}$, true Harjamukti $48 \mathrm{KKS}$, true Kalijaga $63 \mathrm{KKS}$, true Kecapi $42 \mathrm{KKS}$, true Larangan $408 \mathrm{KKS})$. nilai accurasi model algoritma K-Nearst Neighbor sebesar $66.46 \%$.

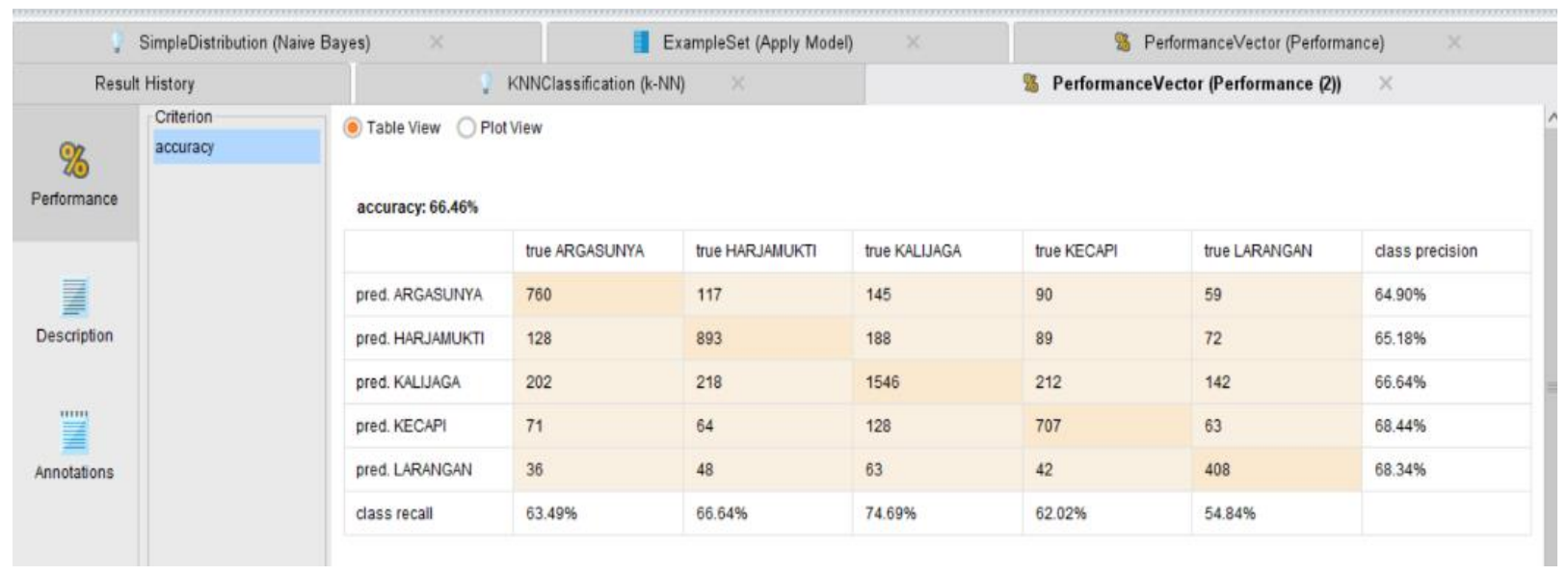

Gambar 5. PerformanceVector Algoritma K-Nearst Neighbor

Berdasarkan tujuan penelitian ini untuk dapat mengetahui performance metode algoritma Naïve Bayes dalam mengklasifikasi data penerima manfaat bantuan non tunai kartu keluarga sejahtera di kecamatan Harjamukti. hasil Klasifikasi Penerima Manfaat Bantuan Non Tunai Kartu Keluarga Sejahtera Menggunakan Metode Naïve Bayes Dan K-Nearst Neighbor dengan performance dari metode algoritma Naïve Bayes menghasilkan nilai accuracy sebesar $99.89 \%$ dan performance metode algoritma K-Nearst Neighbor $66.46 \%$.

\section{KESIMPULAN}

Adapun hasil kesimpulan yang didaptkan dalam penelitian ini pengaruh penggunaan machine learning dalam penentuan warga penerima manfaat bantuan non tunai kartu keluarga sejahtera di kecamatan Harjamukti dari 6.491 penerima KKS dengan metode algoritma Naïve Bayes terklasifikasi dengan true di masing-masing kelurahan dengan sebaran true Argasunya 1.196 KKS class precision 100\%, true Harjamukti $1.339 \mathrm{KKS}$ class precision 100\%, true Kalijaga 2.067 KKS class precision 100\%, true Kecapi 1.137 KKS class precision 100\%, true Larangan $744 \mathrm{KKS}(1$ KKS true Argasunya, 1 KKS true Harjamukti, 3 KKS true Kalijaga, 3 KKS true Kecapi) class precision 98.64\%. nilai accurasi model algoritma Nä̈ve Bayes sebesar 99,88\%. Dan hasil sebaran dengan metode algoritma K-Nearst Neighbor pred Argasunya class precision 64.90\% dengan sebaran (true Argasunya $760 \mathrm{KKS}$, true Harjamukti 117 KKS, true Kalijaga $145 \mathrm{KKS}$, true Kecapi $90 \mathrm{KKS}$, true Larangan $59 \mathrm{KKS}$, pred. Harjamukti class precision $65.18 \%$ dengan sebaran ( true Argasunya 128 KKS, true Harjamukti 893 KKS, true Kalijaga 188, true Kecapi 89 KKS, true Larangan 72 KKS, pred. Kalijaga class precision 66.64\% dengan sebaran (true Argasunya 202 KKS, true Harjamukti $218 \mathrm{KKS}$, true Kalijaga 1.546 KKS, true Kecapi $212 \mathrm{KKS}$, true Larangan $142 \mathrm{KKS}$, pred. Kecapi class precision 68.44\% dengan sebaran (true Argsunya $71 \mathrm{KKS}$, true Harjamukti $64 \mathrm{KKS}$, true Kalijaga $128 \mathrm{KKS}$, true Kecapi 707 $\mathrm{KKS}$, true Larangan $63 \mathrm{KKS}$, pred. Larangan class precision 68.34\% dengan sebaran (true Argsunya $36 \mathrm{KKS}$, true Harjamukti 48 KKS, true Kalijaga 63 KKS, true Kecapi 42 KKS, true Larangan 408 KKS). Berdasarkan hasil dari performance penerapan metode algoritma Naïve Bayes dan K-Nearst Neighbor dalam mengklasifikasi data penerima manfaat bantuan non tunai kartu keluarga sejahtera di kecamatan Harjamukti menghasilkan nilai accuracy sebesar 99.89\% dan performance metode algoritma K-Nearst Neighbor 66.46\%. peneliti menyimpulkan bahwa pengaruh penerapan kedua algoritma tersebut sebaran penerima manfaat bantuan non tunai kartu keluarga sejahtera berdasarkan performance terbaik dengan accuracy $99.89 \%$ adalah menggunakan algoritma Naïve Bayes.

\section{REFERENCES}

[1] G. M. V. K. Helvine Gultom, Paulus Kindangen, "Jurnal Pembanguan Ekonomi dan Keuangan Daerah Vol.20 No.04. Mei 2020," J. Pembang. Ekon. dan Keuang. Drh., vol. 20, no. 4, pp. 39-53, 2020.

[2] D. V. Ferezagia, "Analisis Tingkat Kemiskinan di Indonesia," J. Sos. Hum. Terap., vol. 1, no. 1, pp. 1-6, 2018, doi: 
10.7454/jsht.v1i1.6.

[3] T. Alawiyah, T. Supriatin, H. Sutisna, A. B. Hikmah, and B. K. Simpony, "Implementasi Metode Topsis Pada Sistem Pendukung Keputusan Penerima KKS Pada Desa Tawang,” Indones. J. Softw. Eng., vol. 6, no. 2, pp. 152-162, 2020, doi: 10.31294/ijse.v6i2.8960.

[4] A. Prajoko, R. W. Sembiring, and S. S, "Penerapan Algoritma C4.5 Dalam Klasifikasi Penerima Kartu Keluarga Sejahtera (KKS),” Jurasik (Jurnal Ris. Sist. Inf. dan Tek. Inform., vol. 6, no. 1, p. 171, 2021, doi: 10.30645/jurasik.v6i1.281.

[5] M. A. Suhendra, D. Ispriyanti, and S. Sudarno, "Ketepatan Klasifikasi Pemberian Kartu Keluarga Sejahtera Di Kota Semarang Menggunakan Metode Regresi Logistik Biner Dan Metode Chaid,” J. Gaussian, vol. 9, no. 1, pp. 64-74, 2020, doi: 10.14710/j.gauss.v9i1.27524.

[6] F. Liantoni, "Klasifikasi Daun Dengan Perbaikan Fitur Citra Menggunakan Metode K-Nearest Neighbor," J. Ultim., vol. 7, no. 2, pp. 98-104, 2016, doi: 10.31937/ti.v7i2.356.

[7] H. Annur, "Klasifikasi Masyarakat Miskin Menggunakan Metode Naive Bayes," Ilk. J. Ilm., vol. 10, no. 2, pp. 160-165, 2018, doi: 10.33096/ilkom.v10i2.303.160-165

[8] S. Agribisnis, T. Hias, and B. Adenium, "Jurnal Ilmu Ilmu Agribisnis : Journal of Agribusiness Science , 9 ( 2 ), Mei 2021 Jurnal Ilmu Ilmu Agribisnis: Journal of Agribusiness Science, 9 ( 2 ), Mei 2021 teknik snowball sampling yaitu pemilihan sampel dengan terlebih dahulu menetapkan satu info," vol. 9, no. 2, pp. 191-197, 2021.

[9] R. L. Hasanah, M. Hasan, W. E. Pangesti, F. F. Wati, and W. Gata, "Klasifikasi Penerima Dana Bantuan Desa Menggunakan Metode Knn (K-Nearest Neighbor)," J. Techno Nusa Mandiri, vol. 16, no. 1, pp. 1-6, 2019, doi: 10.33480/techno.v16i1.25.

[10] N. Hadianto, H. B. Novitasari, and A. Rahmawati, "Klasifikasi Peminjaman Nasabah Bank Menggunakan Metode Neural Network,” J. Pilar Nusa Mandiri, vol. 15, no. 2, pp. 163-170, 2019, doi: 10.33480/pilar.v15i2.658.

[11] Wiyanto, "Analisa Tingkat Kepuasan Pelanggan Terhadap Pelayanan Perusahaan Otobus XYZ Menggunakan Metode Naïve Bayes," J. Chem. Inf. Model., vol. 53, no. 9, pp. 1689-1699, 2019.

[12] Z. Arifin, "Penerapan Metode Knn (K-Nearest Neighbor) Dalam Sistem Pendukung Keputusan Penerimaan Kip (Kartu Indonesia Pintar) Di Desa Pandean Berbasis Web Dan Mysql," NJCA (Nusantara J. Comput. Its Appl., vol. 4, no. 1, 2019, doi: $10.36564 /$ njca.v4i1.101.

[13] B. Rahmat C.T.I. et al., "Implemetasi k-means clustering pada rapidminer untuk analisis daerah rawan kecelakaan," Semin. Nas. Ris. Kuantitatif Terap. 2017, no. April, pp. 58-60, 2017. 